\title{
Wenceslao Soto Artuñedo (coord.), El jesuita Pedro Páez. Cartas desde el Nilo Azul, Aranjuez, Xerión Comunicación y Publicaciones, 2020, 510 pp., 24,90€.
}

https://doi.org/10.46543/ISID.2029.1014

El historiador linarense Wenceslao Soto, SJ, ha coordinado un interesante volumen dedicado a un insigne misionero, cuya personalidad y colosales iniciativas no tuvieron el merecido resalte histórico hasta hace pocas décadas. Me refiero al jesuita Pedro Páez Campuzano, nacido en 1564 en la actual localidad de Olmeda de las Fuentes, provincia de Madrid.

Hombre de vasta cultura, inquieto y andariego, con virtudes sobresalientes tanto en el plano espiritual como humano (entre ellas descuella la prudencia), el padre Pedro fue un religioso admirable por su facilidad para las lenguas. Fuerte en la adversidad, nunca se arredró ni echó atrás, sabiendo siempre estar cercano a los grandes de su tiempo sin olvidar a la gente sencilla de Etiopía, país en el que ejerció fecundamente su ministerio sacerdotal, de lo cual da cumplida cuenta este libro. En efecto, ese territorio, por aquel entonces, estaba bastante aislado y era muy arduo llegar a él. Sin embargo, afrontando innumerables escollos, Páez dejó una huella indeleble en el corazón de África. Hoy, sigue siendo acicate para cuantos se acercan a su legado y conocen la herencia que forjó con sus escritos y heroicidades. Tras una luminosa existencia, transida de frutos de bondad, Páez falleció en Gorgorá, Etiopía, en 1622.

Esta monografía quiere rendir tributo a la trayectoria exitosa de este preclaro religioso, destacable por su entrega altruista y su afán de superación. Venciendo enormes dificultades, desarrolló allá por el siglo XVII una intensa labor educadora y evangelizadora en la mencionada nación africana, colmada de cultura, historia y vicisitudes.

Aunque Páez, en particular, es recordado por sus dotes arquitectónicas y haber sido el primer europeo que llegó a las fuentes del Nilo Azul en 1618, ciento cincuenta años antes de que el escocés J. Bruce de Kinnaird aseverara haberlo conseguido, sus logros no pueden quedar restringidos a meros avatares. Precisamente las páginas de esta obra muestran que la riqueza de su figura es igualmente ciclópea por abundantes merecimientos en otras facetas, destacando las de calado espiritual.

Las proezas del padre Páez, de diversa índole e inapreciable alcance, como este volumen manifiesta, por desgracia e inexplicablemente quedaron largo tiempo retenidas en la penumbra de los archivos, estando a disposición solamente de aquellos que accedían a la bibliografía especializada. Con esta obra, afortunadamente, se subsana esta laguna y, dando cauce a la justicia, se sacan a la luz sus gestas, al tiempo que se ponen de 
relieve sus magnas realizaciones y difunde entre el gran público el audaz ejemplo de una vida copiosa de amor a Dios y a los demás.

Esta monografía quiere completar anteriores esfuerzos por divulgar las hazañas de Pedro Páez, sobre todo los llevados a cabo por Juan González Núñez en 1988, y que los encontramos reseñados en la revista "Mundo Negro", y los del periodista Javier Reverte, que en 2001, con su libro "Dios, el diablo y la aventura", popularizó literariamente la figura de Páez, subrayando especialmente su vertiente exploradora y aventurera, el tiempo en el que este egregio jesuita fue esclavo o aquella otra etapa de su vida dedicada a aconsejar a dos emperadores etíopes. Los que colaboran en este volumen, en cambio, han incidido más bien en aspectos de significado eclesial: sus orígenes, sus estudios, su producción epistolar, su vocación y quehacer evangelizador como miembro de la Compañía de Jesús, rastreando para ello fuentes documentales serias y contrastadas.

Este libro es resultado de una granada colaboración. El prólogo corre a cargo de María del Carmen de la Peña Corcuera, embajadora de España ante la Santa Sede, que conoció el periplo de Páez hace lustros, cuando ejerció sus funciones diplomáticas en Etiopía, siendo desde entonces una convencida admiradora de este eximio jesuita español, abanderado en muchas disciplinas. Viene después una breve y enjundiosa introducción a la figura de este misionero por cuenta del escritor Javier Reverte, que como he dicho sacó a este jesuita del anonimato en España.

Luego, el hermano Wenceslao Soto fija su mirada en los años en que Páez permaneció en España, aclarando algunas etapas de su formación e iluminando con esmero las motivaciones que llevaron al religioso a pedir marchar como heraldo del Evangelio a las Indias, aunque luego, sin esperarlo, acabara en Etiopía, donde desplegó una ingente tarea en campos variopintos. Fundamental en este capítulo es el elenco que Soto hace de los escritos de Páez, numerosos y de gran valor histórico.

Sigue, a continuación, una contribución realmente meritoria, pues Soto reproduce un texto que había permanecido hasta ahora inédito. Me refiero a la biografía que compuso de este religioso el historiador oficial de la provincia jesuítica de Toledo, Bartolomé Alcázar (16481721), en gran parte redactada sobre la base de un abanico de cartas escritas por Páez.

Las cartas que no menciona Alcázar aparecen también editadas en este volumen por el doctor Andreu Martínez d'Alós-Moner, investigador que sabe combinar el estudio arqueológico con el análisis histórico. De este modo, este libro posibilita el acceso al epistolario que se ha logrado conservar de Páez, lo cual es digno de encomio y mención. Sabemos, sin embargo, que muchas de sus cartas se perdieron o no se han localizado todavía. Andreu brinda asimismo un par de cartas escritas por un compañero de 
viajes y de cárcel, Antonio de Monserrat, que aportan luces para entender mejor a Páez y su poliédrico testimonio vital y espiritual.

Sugestiva es asimismo la aportación del profesor Víctor Manuel Fernández Martínez, catedrático de la Universidad Complutense de Madrid, que consagra su estudio a las misiones jesuitas en Etiopía (1557-1632), pasando revista a los yacimientos arqueológicos de dichas misiones. Los restos conservados revelan que el gran protagonismo de la Compañía de Jesús en esos primeros años del siglo XVII no tuvo lamentablemente continuidad, pues los jesuitas fueron expulsados del país y el catolicismo se extinguió en Etiopía, siendo en la actualidad una comunidad minoritaria pero dinamizadora.

En su contribución, el padre J. González Núñez, comboniano, bosqueja, en unas páginas de deliciosa lectura, las peripecias de la Iglesia católica en Etiopía desde Páez a nuestros días. Por su parte, el padre Festo Mkenda, SJ, detalla la actividad de la Compañía de Jesús en esta nación africana desde 1945 hasta ahora. Los jesuitas volvieron a Etiopía gracias a la invitación del emperador Haile Selassie (1892-1975), que deseaba comenzar una escuela secundaria en el país y se preguntaba si la Compañía podía ayudar a prestar este servicio. Esta iniciativa imperial fue apoyada por el papa Pío XII, que la alentó y bendijo, y por los superiores jesuitas de ese momento, que la sostuvieron.

Esta obra finaliza con un apéndice onomástico, que recopila datos generales de enclaves y personas, y uno bibliográfico, con un elenco de obras para quien quiera profundizar en alguno de los elementos abordados en esta publicación.

El itinerario humano y misionero de Pedro Páez trazado en esta obra trae a la memoria el semblante de otros célebres jesuitas, contemporáneos suyos, que advirtiendo que Nuestro Señor Jesucristo es horizonte de plenitud y gozo imperecedero para quien se encuentra con Él, se emplearon a fondo para transmitir a otros de palabra y obra su mensaje redentor. Entre ellos cabe citar al padre Alonso de Barzana (1530-1597), que pasó su infancia en Iznatoraf (Jaén) y estudió en la también giennense universidad de Baeza, tutelado por san Juan de Ávila. Gastó su vida evangelizando con pasión e inaudita solicitud América del Sur. Es obligado también señalar a otro ilustre integrante de la Compañía, el padre Diego de Pantoja (1571-1618), que ejerció por aquella misma época su prolífico apostolado en China, como colaborador de Mateo Ricci. Esta triada de religiosos, y otros muchos que fueron discípulos de primera hora de san Ignacio de Loyola, nos despiertan de la apatía e inercia que a menudo nos circunda, nos arrancan de comodidades paralizantes y nos empujan a encarnar el Evangelio desde la valentía y el arrojo, sin demasiados cálculos, a veces incluso andando más allá del sentido común. 
Esto solo es posible cuando se deposita la confianza exclusivamente en Cristo, salvador del hombre y luz de las naciones.

Felicitamos a los autores de esta monografía por su empeño por dar reconocimiento al jesuita Pedro Páez, cuya trayectoria ojalá generara más publicaciones que resaltaran su extraordinaria dimensión humana y creyente. Su figura no solo entraña la de un adalid de su tiempo sino también la de una brújula que no deja de guiar al pueblo de Dios en la hora presente. Pero es justo congratularse asimismo con la Fundación PalArq, con la Embajada de España en Etiopía y con la Agencia Española de Cooperación Internacional para el Desarrollo (AECID), que de diversas maneras han puesto y ponen su granito de arena para repristinar la talla humana, cultural y espiritual de Páez.

Concluyendo, y sumándome al parecer de la embajadora de la Peña, este volumen aclara documentalmente algunos puntos de la vida del padre Páez, a la vez que facilita y estimula el conocimiento de su formidable apostolado. Son páginas que encumbran y resaltan la valía de "este descubridor jesuita español, importante personalidad de nuestra cultura e historia" (pág. 12). Anhelamos que la abnegación de este religioso sirva de paradigma y modelo para las nuevas generaciones y las lleve a apostar por la excelencia, la altura de miras y la hondura de planteamientos. Antaño como hogaño, la vida de Pedro Páez es una antorcha que nos aleja del gris en el que no pocas veces nos instalamos, disipando insensibilidades y egoísmos.

Esta publicación, en definitiva, puede convertirse en una sonora llamada, en un aguijón que nos espolee para que el talante de Pedro Páez y de aquellos otros germinales jesuitas no quede enclaustrado en un pasado remoto ni nos deje indiferentes. Antes bien ha de edificarnos y animarnos a salir de nosotros mismos para abandonar mediocridades, crecer por dentro, optar por la innovación y transitar, en fin, por los caminos del Evangelio, hontanar de esperanza para el hombre y semilla de dignidad para los pueblos.

Fernando Chica Arellano

Observador Permanente de la Santa Sede ante la FAO, el FIDA, y el PMA arellano@libero.it

\section{José Granados - Juan Antonio Granados - Carlos Granados, ¿Tendrán fe nuestros hijos? Educar desde la vida sacramental, Madrid, Didáskalos, 2019, 144 pp., $18 €$.}

https://doi.org/10.46543/ISID.2029.1015

Vivimos tiempos arduos para la educación. Las aulas se han convertido en terreno de un juego político en el que los cambios continuos de leyes 